\title{
SPRAY COOLING OF AIR-COOLED COMPACT HEAT EXCHANGERS
}

\author{
Wen-Jei Yang and D. W. Clark \\ Department of Mechanical Engineering, The University of Michigan, \\ Ann Arbor, Michigan 48104, U.S.A.
}

(Received 21 June 1974)

\begin{abstract}
This paper investigates the technical feasibility of air-cooled :ompact heat exchangers with liquid-droplet spray in a fine mist as a more effective heat rejection system between a condensing vapor or hot fluid system and ambient air. Both water and ethylene glycol are sprayed. Three automotive radiator cores with 3.94 fins per $\mathrm{cm}$ are tested in a wind tunnel. One unit is plain-finned, the second unit louvered, and the third perforated. At essentially no change in the friction coefficient, a good improvement in heat-transfer performance is observed by spraying 1.26 to $2.52 \mathrm{ml} / \mathrm{s}$ of liquid.
\end{abstract}

\section{NOMENCLATURE}

$D_{h}, \quad$ hydraulic diameter [m];

$f$ Fanning friction coefficient [dimensionless];

$G$, mass velocity of air $\left[\mathrm{kg} / \mathrm{m}^{2} \mathrm{~s}\right]$;

$h$ air-side heat-transfer coefficient $\left[\mathrm{W} / \mathrm{m}^{2} \mathrm{~K}\right]$;

$h_{a}$, apparent value;

$h_{w}$, water-side heat-transfer coefficient

$\left[\mathrm{W} / \mathrm{m}^{2} \mathrm{~K}\right]$;

$j, \quad$ heat-transfer factor [dimensionless];

$K, \quad$ pressure drop coefficient [dimensionless];

$K_{c}, \quad$ at core entrance (contraction);

$K_{e}, \quad$ at core exit (expansion);

$L, \quad$ core flow length $[\mathrm{m}]$;

$\Delta P, \quad$ air-side pressure drop $\left[\mathrm{N} / \mathrm{m}^{2}\right]$;

$R e, \quad$ Reynolds number [dimensionless];

$r_{h}, \quad$ hydraulic radius [m];

$t, \quad$ fin thickness [m];

$U, \quad$ overall heat-transfer coefficient between air and hot water $\left[\mathrm{W} / \mathrm{m}^{2} \mathrm{~K}\right]$;

$w_{s}, \quad$ slot gap $[\mathrm{m}]$.

\section{Greek symbols}

$\alpha, \quad$ heat-transfer area/total core volume $\left[\mathrm{m}^{2} / \mathrm{m}^{3}\right]$

$\alpha_{a}, \quad$ air side;

$\alpha_{w}, \quad$ water side;

$\eta_{f}, \quad$ air-side fin effectiveness [dimensionless];

$\eta_{o}, \quad$ air-side overall surface effectiveness

[dimensionless];

$\mu, \quad$ absolute viscosity of air $\left[\mathrm{Ns} / \mathrm{m}^{2}\right]$;

$\rho, \quad$ density of air $\left[\mathrm{kg} / \mathrm{m}^{3}\right]$.

\section{INTRODUCTION}

RECENT studies $[1,2]$ indicate the Rankine cycle power plant has great potential for automotive application with the benefit of low exhaust emission. One of the major limitations in the application of the Rankine cycle in automobiles is the condenser. In the Rankine cycle automotive engine, approximately ten times as much heat as that dissipated in the conventional automotive radiator has to be removed in the condenser. Since the limiting heat transfer is on the air side rather than the liquid or condensing side, and since further increases in fin area per unit matrix volume would result in merely marginal increases in heattransfer performance but with great increases in frictional pressure loss, it is appropriate to search for other methods of heat transfer with substantially increased heat-transfer performance.

It has been shown [3-8] that the addition of small amounts of liquid drops to a cooling gas stream enhances the heat-transfer rates from solid surfaces. When water spray in small amounts is introduced into a gas stream flowing over a heated surface, a thin liquid film is formed and covers a portion of the entire surface. Improvements in heat-transfer performance obtained with these two-phase flows are attributed to evaporation at the interface, forced convection in the thin liquid film and the interaction of the liquid droplets with the liquid film. The increase in heat transfer is clearly a function of the surface area covered by a liquid film, therefore geometric shapes which make possible larger area to be covered by a film is desirable. Goldstein et al. [6], indicated a significant increase in the heat-transfer coefficient with two-phase spray flow over a flat plate. In this case the effects of evaporation and liquid film agitation were neglected. Scherherg et al. [8], have experimentally studied liquid-gas spray flows over a circular cylinder, an elliptical cylinder and a composite geometry consisting of a forward semi- 
circular cylindrical and a downward rectangular section. These three geometries have a common capture area. Results are obtained for the local heat transfer with various ratios of water spray to air mass flow. These results show that the overall heat transfer is increased at least an order of magnitude in comparison to that for air flow alone for the spray/air ratios shown. The effect of liquid evaporation is negligible since the temperature difference between the oncoming twophase flow and the test surface was less than $60^{\circ} \mathrm{F}$. In other spray flow studies. Toda and Uchida [7] have investigated the case of two-phase stagnation flow, i.e. flow perpendicular to a horizontal flat heating surface. The temperature of water droplets ranged from 50 to $100^{\circ} \mathrm{C}$, while that of the heating surface was from a few degrees to $250^{\circ} \mathrm{C}$ higher than the droplet temperature. Therefore, the contribution of liquid evaporation was dominant. Experimental results are obtained for heat flux versus the temperature difference between the heating surface and the liquid droplet, for several different droplet velocities and flow rates. These results are compared with those for forced convection heat transfer to water inside tubes with and without boiling, taken from [9]. The heat-transfer coefficient corresponding to the lowest set of data points for the twophase spray flow is on the order of $11300 \mathrm{Wm}^{-2} \mathrm{~K}^{-1}$. This value is approximately 100 times that of the air side heat-transfer coefficient in conventional finned tube heat exchangers. It is illustrated that the heattransfer performance with two-phase spray flows could be better than that for pool boiling in saturated liquids.

In the present study, three plate-finned automotive radiator cores, plain-fin, louvered and perforated, are tested in a wind tunnel with hot water flowing inside tubes and two-phase spray flow on the air side. The fine droplets of liquid, water and ethylene glycol, is sprayed in the air stream. The so-called "steady-state method" is employed in determining the heat-transfer performance of the core. Results of the heat transfer and pressure drop performance on the cold-fluid side are compared with those oblained for single-air flows. Applications of the study include automobile radiators, environmental system condensers, air-cooled condensers for the marine power propulsion systems, the Rankine cycle automotive engines, and the dry-cooling towers of electric power plants, and air-water heat exchangers.

\section{EXPERIMENTAL APPARATUS AND PROCEDURE}

An automotive radiator core installed in a subsonic wind tunnel was heated by hot water at about $88^{\circ} \mathrm{C}$ and $1.38 \times 10^{5} \mathrm{~N} \mathrm{~m}^{-2}$ gage flowing in a closed loop. For wet runs, water and ethylene glycol were sprayed into the stream of air. The so-called "steady-state method" was employed in determining the heat-transfer performance of the core.

\section{Heat transfer apparatus}

The experimental setup used to investigate the heat transfer and friction loss performance of the liquid spray heat exchanger consisted of a test core mounted in a subsonic wind tunnel. Upstream of the heat exchanger test core were four symmetrically placed spray nozzles to generate the air-water mixture. The heat exchanger test cores have frontal area of 30.5 by $30.5 \mathrm{~cm}$ and thickness of $7 \mathrm{~cm}$. They are finned-tube surfaces, flat tubes, continuous fins. Tube dimensions are $0.33 \mathrm{~cm}$ (perpendicular to air flows) by $1.81 \mathrm{~cm}$ (parallel to flow) with distance between centers parallel to flow of $0.914 \mathrm{~cm}$, i.e. fin length of $0.185 \mathrm{in}$. The fins are made of copper having thickness of $7.62 \times 10^{-3} \mathrm{~cm}$ and pitch of 3.94 fins per $\mathrm{cm}$, most commonly used in automotive radiators. The flow passage hydraulic radius is $0.0976 \mathrm{~cm}$. The ratios of total area to total volume, fin area to total area, and free flow area to frontal area are $230,0 \cdot 818$ and 0.719 , respectively. Of the three cores, one is plain-finned, the second unit louvered, and the third perforated. The louvered-finned unit has eleven louvers in $1.9 \mathrm{~cm}$ (i.e. louver spacing of $0.173 \mathrm{~cm}$ ), each $0.634 \mathrm{~cm}$ (louver width) $\times 0.0397 \mathrm{~cm}$ (louver gap) in size and approximately $30^{\circ}$ angle. In case of the perforated finned unit, each slot is rectangular $0.634 \times 0.159 \mathrm{~cm}$ in size with three slots in $1.9 \mathrm{~cm}$. Hot water flowed inside flat tubes, $0.317 \times 1.9 \mathrm{~cm}$ in size, which were in staggered arrangement with the transverse and longitudinal pitches of 1.27 and $2.54 \mathrm{~cm}$, respectively.

Water at approximately $88^{\circ} \mathrm{C}$ and $1.38 \times 10^{5} \mathrm{~N} \mathrm{~m}^{-2}$ gage was used as the hot fluid. The inlet water temperature to the core was maintained at an approximately constant temperature by an external shell and tube heat exchanger. (A steam regulator was installed upstream of the heat exchanger and a combination of the regulator setting, heat exchanger throttle valve position, and bypass cooler operating condition resulted in a maximum variation of radiator inlet water temperature of $0.28^{\circ} \mathrm{C}$.) The inlet and exit water temperatures of the test core were measured using 30 gage copper-constantan thermocouples and a Leeds and Northrup (model 8662) potentiometer. The water flow rate was measured using a standard $2.86 \mathrm{~cm}$ orifice flow meter and a King manometer (model BSS 50) with a fluid having a specific gravity of $2 \cdot 94$.

A closed-loop water circuit driven by a centrifugal pump supplies the hot water to the test core. The control of the flow through the system was by means of a pump bypass, a pump discharge throttle valve, and a vernier bypass valve around the main control valve. An accumulator was installed upstream of the test core 
inlet to maintain a given pressure level. A bypass cooler in parallel with the test core permitted the system to be operated without the test core in the circuit and also was useful in stabilizing the system when tests were run at low mass flow and heat flow rates.

In order to produce the fine liquid droplets on the air side four $4.55 \times 10^{-3} \mathrm{~m}^{3} / \mathrm{h}$ oil burner nozzles were installed upstream of the test core. These were symmetrically located so as to ensure a uniform contact of liquid droplets over the entire test core surface. The water and ethylene glycol spray flow rates were measured by a standard $0.132 \mathrm{~cm}$ orifice and a Merian manometer (model BS 10) with a fluid of specific gravity 2.0. All the orifice flow meters were calibrated.

\section{Wind tunnel}

The wind tunnel consisted of a contraction section, test section $(61 \times 61 \mathrm{~cm}$ cross section), diffuser, fan, and discharge ducting. It was designed specifically for testing both scale models and full size automotive radiators, environmental system condensers and liquidair heat exchangcrs.

Since the frontal area of all of the test cores was less than the wind tunnel test section area, baffles of constant area section were installed immediately upstream as well as downstream of the core. A bellmouth in the inlet end of the constant area section was used to insure proper inlet flow conditions.

Two pitot tubes were inserted into the constant area sections, one at upstream and the other at downstream from the core. The pitot tubes were connected to a CGS (CGS Scientific Corporation) type 531-1 differential pressure transducer with a CGS type 1023 electronic manometer to read four pressure differences: total to static pressure differences at both upstream and downstream and total to total and static to static pressure differences between upstream and downstream. The air velocities at the inlet and exit of the test core and the static, dynamic and total friction losses in the test core were evaluated from these pressure measurements. Temperatures were measured by copper-constantan thermocouples and read on an L\&N 8662 precision potentiometer. The inlet air temperature was read by a thermocouple located near the tip of the upstream pitot tube.

\section{Test procedure}

Test procedure consists of:

(a) Fill system with water.

(b) Operate pump while continuing to add and bleed water and air from the system.

(c) When bleeding of air is complete, turn on steam supply to bring water temperature to about $85^{\circ} \mathrm{C}$, while keeping a small addition and bleed of water. (d) Start fan and when steady state temperatures have been established shut off water addition and bleed, thus isolating the system.

(e) Set desired air velocity through test section by means of bypass opening, set desired water flow rate using throttle valve, and set radiator water inlet temperature by adjusting setting of steam pressure regulator.

(f) When steady state values have been reached, record radiator water and air temperatures and pressures and flow rates.

(g) Repeat steps (e) and (f) for successive data points.

\section{Data reduction}

The steps in the data reduction requires the determination, in the order given, of the following factors. The physical properties of air and water have been represented by equations from [10-13]. A digital computer was used for numerical computations.

(i) Surface characteristics. This includes the calculations of the frontal area, flow-passage hydraulic radius, total heat-transfer area to total core volume ratio, free-flow area to frontal area ratio on both the hot- and cold-fluid sides, the fin area to total heattransfer area ratio, and the total core volume. The fin is $7.62 \times 10^{-3} \mathrm{~cm}$ thick, made of copper, and its length is one-half distance between tubes.

(ii) Fluid properties. The bulk average air and water temperatures were employed to evaluate fluid propertics. An arithmetic mean between inlet and outlet measurements is the bulk average water temperature, while the average air temperature is based on the logarithmic mean for true counterflow. The ambient relative humidity is determined by wet and dry bulb temperature upstream of the spray nozzles. This value is then used to modify the moist air specific heat and density. The change in humidity across the test cores was found to be very small and therefore no additional corrections are made for the amount of water vapor increase as the air flows through the test core.

(iii) Reynolds numbers. The mass flow rate of the air is determined by the Bernoulli's theorem using the total to static pressure difference at upstream. The Reynolds number on each side is defined based on the flow-passage hydraulic radius $r_{h}: R e=4 r_{h} G / \mu$, where $G$ is the mass velocity and $\mu$ is the absolute viscosity.

(iv) Air-side Fanning friction coefficient $f$. The airside pressure drop, $\Delta P$ the static to static pressure difference between upstream and downstream, is

$$
\Delta P=G^{2}\left(K_{c}+f L / r_{h}+K_{e}\right) / 2 \rho
$$

from which $f$ is calculated. Here, $L$ is the flow length, $\rho$ is the air density $K_{c}$ and $K_{e}$ are the pressure loss coefficient at core entrance and exit, respectively, and are determined using Fig. 5-3 of [14]. Since the change 
in air temperature across the core is not large, the effects on pressure drop due to flow acceleration and density change through the core are negligible.

(v) Overall heat-transfer coefficient between the fluids $U$ (based on the air-side area). Assuming no heat loss to the surroundings, $U$ is evaluated based on the enthalpy change of water and the true mean temperature difference between the fluids.

(vi) Heat-transfer coefficients $h$. The water-side heattransfer coefficient $h_{w}$ is determined by means of the Boelter equation for turbulent flow inside tubes, since the water-side Reynolds numbers are either very close to or over 10000 . A value of the air-side heat-transfer coefficient $h_{a}$ is assumed. In case of spray (or wet) runs, $h_{a}$ corresponds to the apparent value as if mass transfer does not exist and the overall increase in heat transfer is attributed solely to an increase in convective contribution. The fin effectiveness $\eta_{s}$ for straight fins is calculated by one-dimensional fin analysis. It is followed by the evaluation of the overall air-side surface effectiveness $\eta_{0}$. The assumed $h_{a}$ must satisfy the equation $1 / U=1 / \eta_{o} h_{a}+1 /\left(\alpha_{w} / \alpha_{a}\right) h_{w}$ for neglecting the very small wall resistance. Otherwise, a new value of $h_{a}$ is selected and the procedure is repeated.

(vii) Air-side heat-transfer factor $j$. The last step is to determine the $j$ factor, defined as the product of the Stanton number and the two-thirds power of the Prandtl number.

Because of very small changes in the saturated temperatures of the air-vapor mixtures between the inlet and outlet of the test core, accurate measurements of changes in the wet-bulb temperatures across the core were very difficult particularly for low spray runs. However, the heat balance between the hot- and coldfluid sides of the test core was very satisfactory within \pm 10 per cent. The probable uncertainty in the test data, although varying somewhat for different test cores and for different air-flow rates, was conservatively estimated to be within \pm 5 per cent for both heattransfer and friction loss measurements.

\section{TEST RESULTS AND DISCUSSION}

Results for the air-side heat-transfer coefficient $h$, overall heat-transfer coefficient between hot water and air $U$, heat-transfer factor $j$, and Fanning friction coefficient $f$ vs the Reynolds number are presented in Figs. 1-6. In addition to dry runs using the room air, two series of spray cooling tests were conducted on each core: 3.62 and $7.7 \mathrm{~kg} / \mathrm{h}$. Only those test data having heat balance between the enthalpy changes of the hot and cold fluid sides not more than 10 per cent were plotted in the figures. In each series of the tests, dry and two spray runs, approximately 100 tests were conducted on each core for the Reynolds numbers ranging between 400 and 8000 . Similar tests with the

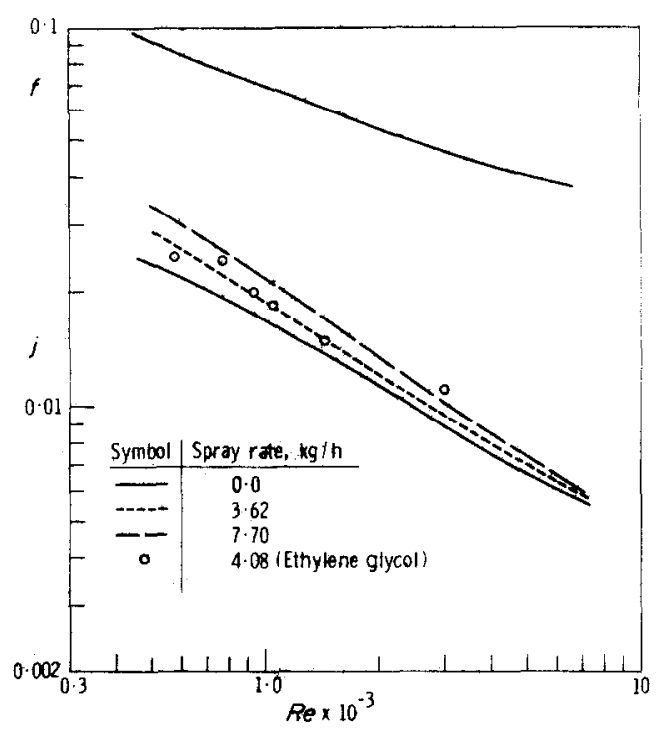

FIG. 1. $f$ and $j$ vs Re for louvered-finned tubular heat exchanger.

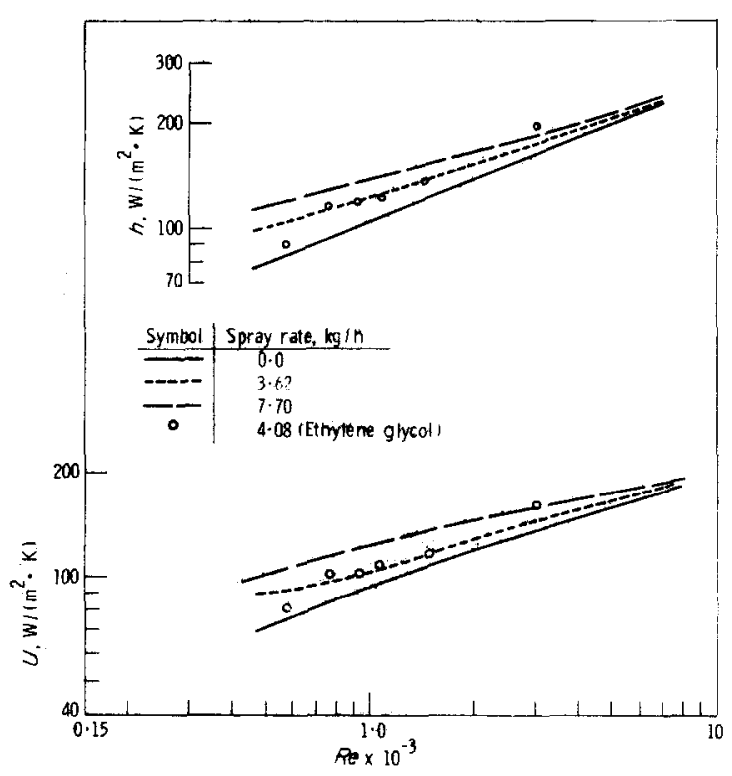

FIG. 2. $h$ and $U$ vs $R e$ for touvered-finned tubular heat exchanger.

spray of ethylene glycol were conducted on the louvered-finned core.

It is rather difficult to pinpoint the Reynolds number for transition from laminar into turbulent flow, by examining the data on the figures and also referring to the available information on similar units [14]. In case of the plain-finned unit, the transition is estimated to be at $R e$ of about $\mathbf{3 0 0 0}$. However, when fins are louvered or perforated as in the other two units, an earlier 


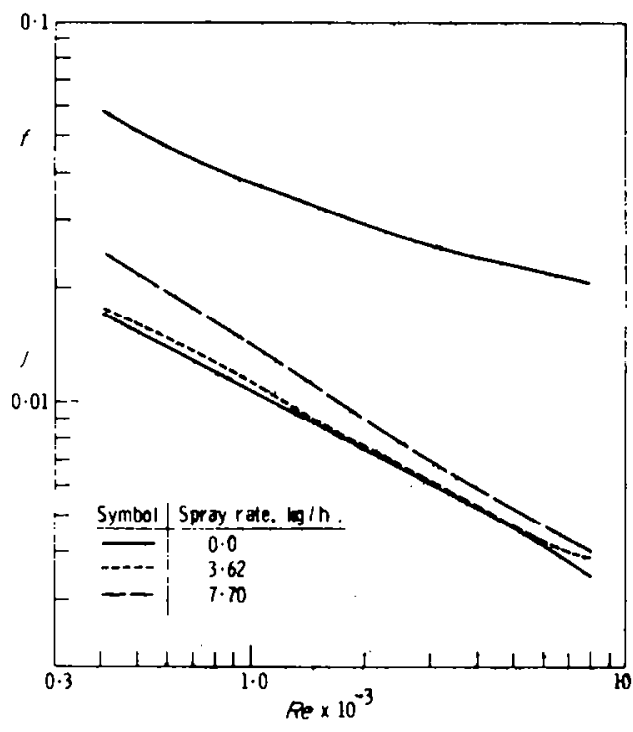

FIG. 3. $f$ and $j$ vs Re for perforated-finned tubular heat exchanger.

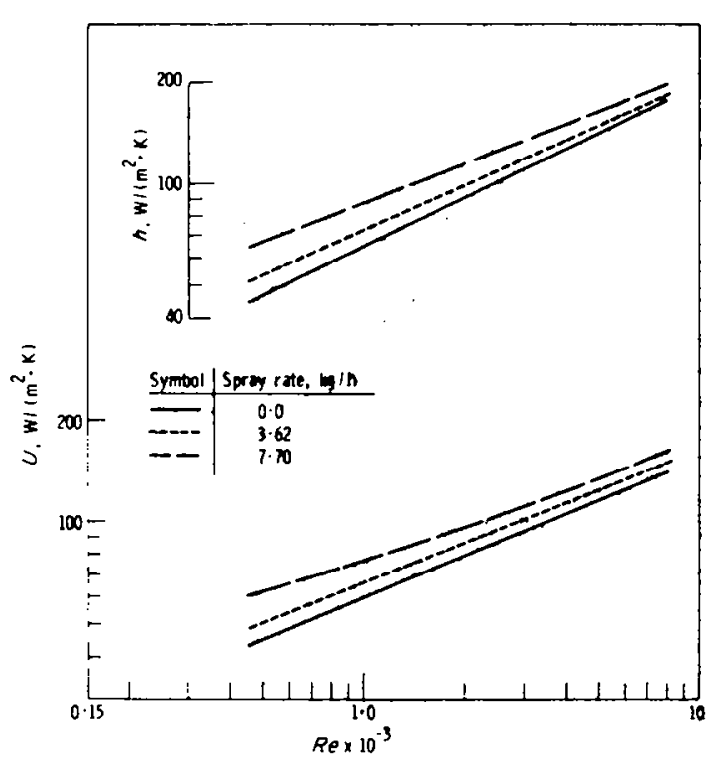

FIG. 4. $h$ and $U$ vs $\operatorname{Re}$ for perforated-finned tubular heat exchanger.

transition is expected because of flow disturbance due to louvers and perforations.

The test results on $f$ and $j$ for dry runs in the plain-finned unit are compared with those available in [14]: Figures $10-88$ and $89\left(1.02 \times 10^{-2} \mathrm{~cm}\right.$ copper fins, fin pitch $=3.65$ and 4.46 per $\mathrm{cm}, D_{k}=0.412$ and $0.351 \mathrm{~cm}$ ). The $j$ values agree well, while the $f$ curve is parallel but lower for the present unit.

It is observed in the figures that water spray does

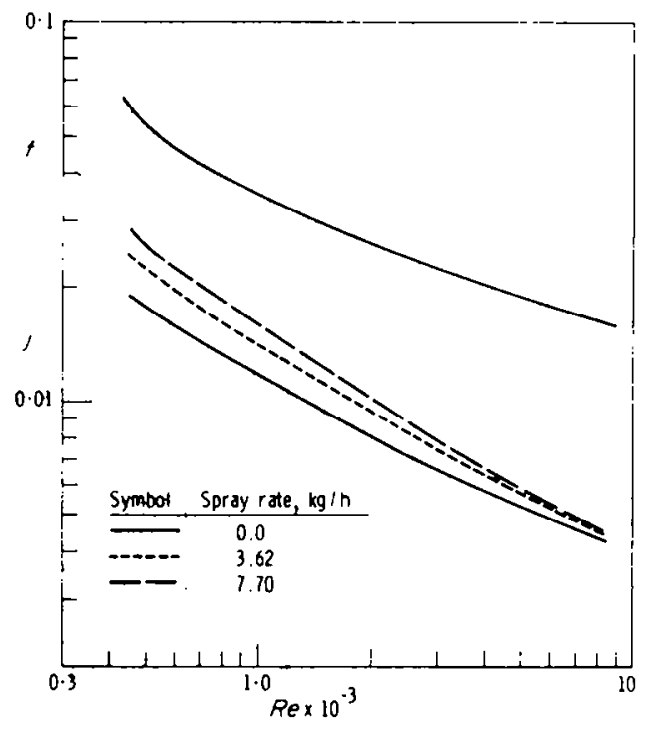

FIG. 5. $f$ and $j$ vs $R e$ for plain-finned tubular beat exchanger.

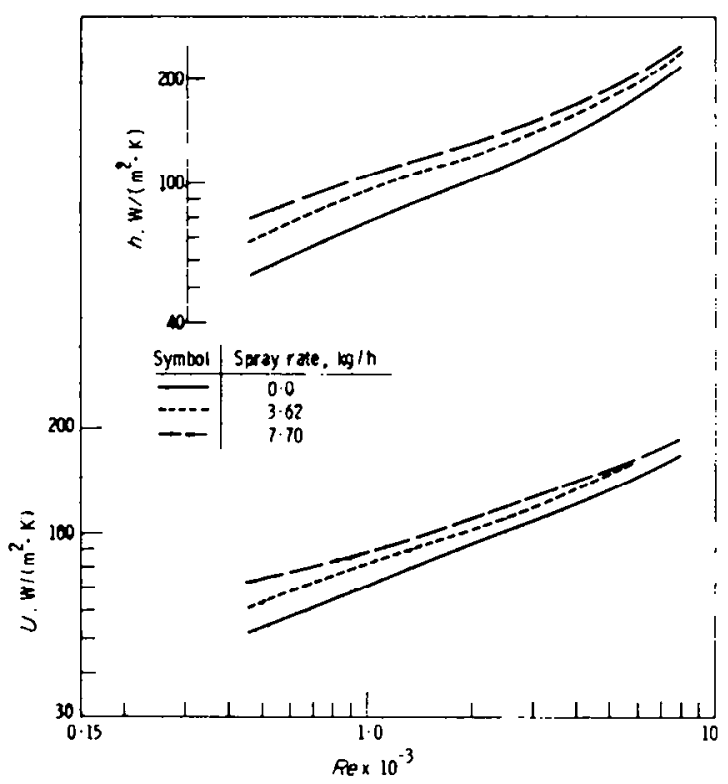

FK, 6. $h$ and $U$ vs $R e$ for plain-finned tubular heat exchanger.

not alter the friction factors in all three units. However. the spray has appreciably increased heat-transfer performance, $h$ and consequently $U$. This increase is most pronounced in low Reynolds numbers or the laminar flow regime, about $45-40$ per cent in the range of $R e=500-1000$ as ilhustrated in Table 1. The spray effects on heat-transfer performance continue to reduce as flow rate is increased. In the turbulent regime, gains in the apparent and overall heat-transfer coefficients 
Table 1. Increases in $h$ and $U$ due to liquid spray

\begin{tabular}{lrrr}
\hline Fin surface & Re & $\begin{array}{c}h \\
(\%)\end{array}$ & $\begin{array}{c}U \\
(\%)\end{array}$ \\
\hline \multirow{3}{*}{ Plain } & 500 & $45 \cdot 0$ & $40 \cdot 4$ \\
& 1000 & $34 \cdot 0$ & $30 \cdot 0$ \\
& 7000 & $12 \cdot 7$ & $12 \cdot 7$ \\
Louvered & 500 & $44 \cdot 4$ & $40 \cdot 6$ \\
& 1000 & $30 \cdot 3$ & $28 \cdot 5$ \\
Perforated & 7000 & $6 \cdot 2$ & $6 \cdot 1$ \\
& 500 & $44 \cdot 5$ & $41 \cdot 0$ \\
& 1000 & $33 \cdot 0$ & $29 \cdot 2$ \\
& 7000 & $13 \cdot 5$ & $12 \cdot 5$ \\
\hline
\end{tabular}

are about 12 or 13 per cent for the plain and perforated units and about 6 per cent for the louvered unit. This is believed to be a result of the fact that louvers have promoted turbulence in the core and as a consequence a thin water film cannot adhere to the fin surfaces to improve heat-transfer performance through liquid layer. Perforation can also promote turbulence like louvers. However, in the present perforated finned core, the ratio of the slot gap (dimension in the flow direction) to the fin thickness $w_{s} / t$ is so large, 0.159 to $7.62 \times 10^{-3} \mathrm{~cm}$ or about 21 , that its role in promoting turbulence does not exist. On the contrary, the large ratio has contributed to a substantial reduction in fin surface area for the heat transfer. As a result, heattransfer performance in the perforated-finned unit, $j, h$ or $U$ is lower than both the plain- and louvered-finned units. The $w_{s} / t$ ratio best for turbulence promotion is known to be from 2.75 to 4 according to the visualization study of [15] and the $f$ and $j$ test results of [16]. For $w_{s} / t$ of 3 , the perforated-finned unit has to have the slot size of $1.52 \times 10^{-2} \mathrm{~cm}$ gap in order to show better heat-transfer performance than the other two units. In view of very high fabrication cost, related to the design and construction of a die set for only fabricating one unit, the perforated-finned unit used the fins whose slots were manually punched using a $0.634 \times 0.159 \mathrm{~cm}$ die. It is strongly emphasized that the objective of the present study is to determine the spray effects on heat-transfer performance and to compare these effects among three typical fins. Accordingly, the results obtained from this study should not be used as a basis for judging the merits of perforated finned units.

Table 2 compares some physical properties of water and ethylene glycol at normal pressure. It is important to point out that ethylene glycol evaporates at $197^{\circ} \mathrm{C}$ compared to $100^{\circ} \mathrm{C}$ in case of water. Yet, the test results for ethylene glycol spray as illustrated in Figs. 1 and 2 show little difference from those for water spray. This indicates that the contribution of evaporation to increase in the heat-transfer performance by means of liquid spray is negligible.

\section{CONCLUSION}

The effects of water and ethylene glycol spray on the heat-transfer and friction loss performance of three automotive radiator cores, tubular types with the plain, louvered, and perforated fins were experimentally investigated in a subsonic wind tunnel.

It has been found that friction losses are not affected by the sprays, while the heat-transfer performance is substantially increased. Improvement in both the apparent and overall heat-transfer coefficients amount to about 45-40 per cent for the air Reynolds numbers of 500 and 1000 , respectively. These effects decrease as air-side Reynolds number is increased. In the turbulent regime, the increases in the heat-transfer coefficients are about 12 and 6 per cent for the plain- and perforatedfinned units and the louvered-finned core, respectively. The lower rate of improvement in heat-transfer performance with an increase in air-side Reynolds number is due to break up of thin liquid films formed on the fin surfaces. The sprays of water and ethylene glycol yield essentially the same results in spite of the fact that ethylene glycol evaporates at the temperature $\left(197^{\circ} \mathrm{C}\right)$ twice higher than water $\left(100^{\circ} \mathrm{C}\right)$. One may thus conclude that the augmentation of air-side convective heat transfer by liquid spray is mainly due to the formation of liquid film on the heat-transfer surface while the contribution of evaporation is rather negligible, at least in this application.

Table 2. Comparison of physical properties of water and ethylene glycol at normal pressure and $80^{\circ} \mathrm{C}$

\begin{tabular}{lccc}
\hline Physical property & Unit & Water & $\begin{array}{c}\text { Ethylene } \\
\text { glycol }\end{array}$ \\
\hline Boiling point & ${ }^{\circ} \mathrm{C}$ & 100 & 197 \\
Heat of vaporization & $\mathrm{cal} / \mathrm{g}$ & $551 \cdot 7$ & $191 \cdot 12$ \\
Thermal conductivity & $\mathrm{cal} / \mathrm{s}-\mathrm{cmn}^{\circ}{ }^{\circ} \mathrm{C}$ & $1.578 \times 10^{-3}$ & $6.443 \times 10^{-4}$ \\
Specific gravity & $\mathrm{g} / \mathrm{cm}^{3}$ & 0.972 & 1.085 \\
Absolute viscosity & $\mathrm{cP}$ & 0.3565 & 3.02 \\
Specific heat & $\mathrm{cal} / \mathrm{g}^{\circ} \mathrm{C}$ & 1.0023 & 0.73 \\
\hline
\end{tabular}


Acknowledgements-The study was supported by the National Science Foundation under grant number GK 33814.

\section{REFERENCES}

1. J. A. Hoess, Study of unconventional thermal, mechanical and nuclear low pollution-potential power source for urban vehicles, Report to U.S. Department of HEW, NAPCA (March 15, 1968).

2. Staff Report. The search for a low-emission vehicle, Prepared for the Committee on Commerce, United States Senate (1969).

3. T. Elperin, Heat transfer of two-phase flow with a bundle of tubes, Inzh. Fiz. Zh. 4, 30-35 (1961).

4. A. Acrivos, J. E. Ahern and A. R. Nagy, Research investigation of two-component heat transfer, The Marquart Corporation ARL 64-1161, WrightPatterson AF B (1964).

5. M. E. Goldstein, Wen-Jei Yang and J. A. Clark, Momentum and heat transfer in laminar flow of gas with liquid-droplet suspension over a circular cylinder, J. Heat Transfer 89C, 185-194 (1967).

6. M. E. Goldstein, W.-J. Yang and J. A. Clark, Boundarylayer analysis of two-phase flow over an oscillating flat plate, $A I A A J l 5,43-50$ (1967).

7. S. Tora, A study of mist cooling - thermal behaviors of liquid films formed from mist drops on a heated surface at high temperatures and high heat fluxes, Doctoral Thesis, Department of Mechanical Engineering, University of Tokyo, Japan (1968); also published in Proc. 4th Int. Heat Transfer Conference, Paris Versailles, vol. 5, B 5.3 (1970), with H. Uchida as the co-author.
8. M. G. Scherberg, H. E. Wright and W. C. Elrod, Heattransfer potential of liquid-gas spray flows, Int. Symposium on Two-Phase Systems, Technion, Israel (August, 1971).

9. W. H. McAdams, W. E. Kennel, C. S. Minden, R. Carl, P. M. Picornell and J. E. Drew, Heat transfer at high rates to water with surface boiling, Ind. Engng Chem. 41, 1945-1953 (1949).

10. Y. S. Touloukian, P. E. Liley and S. C. Saxena, Thermal conductivity - nonmetallic liquids and gases, in Thermophysical Properties of Matter, The TPRC (Thermophysical Properties Research Center, Purdue Univ., Lafayette, Inc.) Data Series, Vol. 3. IFI/Plenum, New York (1970).

11. A. G. Hanson, Fluid Mechanics. John Wiley, New York (1967).

12. J. H. Keenan and F. G. Keyes, Thermodynamic Properties of Steam. John Wiley, New York (1969).

13. Psychrometrics, in ASHRAE Handbook of Fundamentals, Chapter 5, p. 98. Amer. Soc. Heating, Refrigerating and Air-Conditioning Engrs, New York (1972).

14. W. M. Kays and A. L. London, Compact Heat Exchangers, 2nd Edn. McGraw-Hill, New York (1964).

15. R. H. Shah and H. H. Osborn, Advanced heat exchanger design of compact heat exchangers when operating in a marine environment, Air Preheater Company, Wellesville, New York (1967).

16. C. Y. Liang, Heat transfer and friction loss performance of perforated surfaces, Doctoral Thesis, Department of Mechanical Engineering, University of Michigan, Ann Arbor, Michigan (1974).

\title{
ECHANGEURS DE CHALEUR COMPACT A AIR AVEC REFROIDISSEMENT PAR PULVERISATION
}

\begin{abstract}
Résumé-On étudie les possibilités techniques des échangeurs compacts à refroidissement par air avec projection de gouttes liquides en fin brouillard, dans le cas d'un système à rejet de chaleur entre une vapeur qui se condense, ou un fluide chaud, et l'air ambiant. On pulvérise de l'eau et de l'éthylène glycol. Trois éléments de radiateurs à 3,94 ailettes par $\mathrm{cm}$ sont essayés dans une soufflerie. Un modèle est entièrement aileté, le second est à ouverture et le troisième est perforé. Sans changement sensible du coefficient de frottement, on observe des bonnes performances thermiques en pulvérisant de 1,26 à $2,52 \mathrm{~cm}^{3} / \mathrm{s}$ de liquide.
\end{abstract}

\section{ZERSTÄUBUNGSKUHLUNG BEI LUFTGEKUHLTEN WÄRMEUBERTRAGERN}

Zusammenfassung-Diese Arbeit untersucht die technischen Möglichkeiten der Flüssigkeitszerstäubung als feiner Nebel zur Verbesserung der Wärmeübertragung bei luftgekühlten Wärmeübertragern zwischen einem kondensierenden Dampf oder heißen Fluid und der Umgebungsluft. Die Einspritzung wurde mit Wasser und Äthylglykol durchgeführt. Drei Kraftfahrzeugkühler mit 3,94 Rippen/cm wurden in einem Windkanal geprüft. Der erste Kühler hatte ebene Rippen, bei demzweiten waren die Rippen mit Schlitzen versehen, bei dem dritten waren die Rippen perforiert. Die Widerstandsziffer ändert sich durch die Zerstäubung nicht wesentlich, eine bemerkenswerte Verbesserung der Wärmeübertragungsleistung konnte durch Einspritzen von 1,26 bis $2,52 \mathrm{~cm}^{3} / \mathrm{s}$ Flüssigkeit verzeichnet werden.

\section{ФОРСУНОЧНОЕ ОХЛАЖДЕНИЕ КОМПАКТНЫХ ТЕПЛООБМЕННИКОВ С ВОЗДУШНЫМ ОХЛАЖДЕНИЕМ}

\footnotetext{
Аннотация - В цанной работе исследуется целесообразность применения охлаждаемых воздухом компактных теплообменников с распыливанием жидкости дпя конденсации пара ипи ох.аждения воды. Для впрыскивания используется как вода, так и этиленгликоль. Три автоматические сотовые трубки радиатора с плотностью 3,94 ребра на сантиметр испытывались в аэродинамической трубе. Одна ячейка имела плоские ребра, вторая - жалюзи, а третья была перфорирована. Коэффициент трения практически не изменялся, и при этом наблюдалось хорошее улучшение тепловых характеристик при распылении жидкости от 1,26 до $2,52 \mathrm{~cm}^{3} / \mathrm{cek}$
} 